\title{
Correction: Loss of tuberous sclerosis complex 2 sensitizes tumors to nelfinavir-bortezomib therapy to intensify endoplasmic reticulum stress-induced cell death
}

\author{
Charlotte E. Johnson ${ }^{1} \cdot$ Elaine A. Dunlop ${ }^{1} \cdot$ Sara Seifan $^{1} \cdot$ Henry D. McCann ${ }^{1} \cdot$ Trevor Hay $^{2} \cdot$ Geraint J. Parfitt $\mathbb{D}^{2}$. \\ Ashley T. Jones ${ }^{1} \cdot$ Peter J. Giles ${ }^{1} \cdot$ Ming H. Shen ${ }^{1} \cdot J_{\text {Julian R. Sampson }}{ }^{1} \cdot$ Rachel J. Errington $^{1} \cdot$ D. Mark Davies ${ }^{1,3}$. \\ Andrew R. Tee ${ }^{1}$
}

Published online: 8 January 2019

(c) The Author(s) 2019. This article is published with open access

\section{Correction to: Oncogene}

https://doi.org/10.1038/s41388-018-0381-2

This article was originally published under standard licence, but has now been made available under a CC BY 4.0 license. The PDF and HTML versions of the paper have been modified accordingly.
Andrew R. Tee

teea@cardiff.ac.uk

1 Division of Cancer and Genetics, Cardiff University, Heath Park, Cardiff CF14 4XN, UK

2 European Cancer Stem Cell Research Institute, Cardiff University, Hadyn Ellis Building, Maindy Road, Cardiff CF24 4HQ, UK

3 Department of Oncology, South West Wales Cancer Centre, Singleton Hospital, Swansea SA2 8QA, UK
Open Access This article is licensed under a Creative Commons Attribution 4.0 International License, which permits use, sharing, adaptation, distribution and reproduction in any medium or format, as long as you give appropriate credit to the original author(s) and the source, provide a link to the Creative Commons license, and indicate if changes were made. The images or other third party material in this article are included in the article's Creative Commons license, unless indicated otherwise in a credit line to the material. If material is not included in the article's Creative Commons license and your intended use is not permitted by statutory regulation or exceeds the permitted use, you will need to obtain permission directly from the copyright holder. To view a copy of this license, visit http://creativecommons. org/licenses/by/4.0/. 